\title{
REINTERPRETATION OF THE FIRST STEP OF THE SEQUENTIAL EXTRACTION PROPOSED BY THE SMT
}

\author{
M. ROCCO*, MARÍA. A. RUBIO \\ Laboratorio de Cinética y Química Ambiental, Departamento de Ciencias del Ambiente, Facultad de Química y Biología, \\ Universidad de Santiago de Chile. \\ (Received: November 3, 2008 - Accepted: July 29, 2009)
}

\begin{abstract}
Samples of sediment from Estero Rungue, north of Santiago, were analyzed during January 2007. The studied zone is affected by acid contamination. Analysis of the sediment by XRD detected the presence of rozenite $\left(\mathrm{FeSO}_{4} \cdot 4 \mathrm{H}_{2} \mathrm{O}\right)$ and gypsum $\left(\mathrm{CaSO}_{4} \cdot 2 \mathrm{H}_{2} \mathrm{O}\right)$. The experiments were carried out according to the criterion established for the first Step of the sequential extraction proposed by the SMT, using $\mathrm{Ca}, \mathrm{Cu}, \mathrm{Fe}, \mathrm{Ni}$ and $\mathrm{Zn}$ sulfates in the form of $\mathrm{M}_{\mathbf{x}} \mathrm{SO}_{4} \alpha \mathrm{H}_{2} \mathrm{O}$ as a model sediment. The results suggest that it is possible to extract up to $\sim 99 \%$ of the sulfates because of the low pH ( $\sim 3)$. Analysis of the sediment by XRD before and after the first Step of the sequential extraction showed that the sulfates disappear after the treatment, extending the interpretation of the first Step of the sequential extraction to elements that are interchangeable, adsorbed on carbonates, and present as sulfates.
\end{abstract}

Keywords: Trace metals, sediments, sequential extraction, sulfates.

\section{INTRODUCTION}

For years sequential extraction (SE), proposed originally by Tessier, ${ }^{1}$ has been widely used to determine the conditions under which the metals that are being studied will be set free from the mineral matrix. Recently, however, the use of sequential extraction has been modified with the purpose of increasing the method's efficiency, giving rise to a number of variations that have been analyzed by various researchers ${ }^{2,3}$ as well as by the International Union of Pure and Applied Chemistry (IUPAC). In this paper we propose a new interpretation of the first Step of the four-Step sequential extraction proposed by the Standards, Measurements and Testing program of the European Community (SMT, previously BCR), which does not consider the extraction of metals associated with sulfates in the first Step of SE. The four-step SE proposed by the SMT is carried out by extracting metals from the sediment in the following sequential steps: Extraction 1: Trace metals adsorbed on ores or minerals contained in minerals soluble in weak acid (e.g., carbonates). Extraction 2: Trace metals strongly attached to reducible minerals such as $\mathrm{Fe}$ and Mn hydroxides. Extraction 3: Trace metals strongly attached to oxidizable minerals such as sulfides, phosphates, and organic matter; Extraction 4: Trace metals in ores such as silicates and/or oxides.

\section{MATERIALS AND METHODS}

\section{Sampling}

Two river sediment samples were obtained in January 2007 from a single main in the zone of Rungue ( $\left.30^{\circ} 00^{\prime} 25.55^{\prime \prime} \mathrm{S}, 70^{\circ} 53^{\prime} 34.68^{\prime \prime} \mathrm{W}\right), 50 \mathrm{~km}$ from Santiago (Fig. 1a). In this zone an acid contamination occurs that affects the source of Rungue stream over an extension not larger than $800 \mathrm{~m}$. The physicochemical parameters of the stream are the following: superficial $\mathrm{pH}$ $\sim 3.0, \mathrm{Eh} \sim 400(\mathrm{mV}), \mathrm{TDS} \sim 1500(\mathrm{mg} / \mathrm{L}), \mathrm{SO}_{4}^{2-} \sim 3800(\mathrm{mg} / \mathrm{L})$. From the zone of maximum concentration (Fig. 1b) $250 \mathrm{~g}$ of sediment were collected in-situ by using a PVC core-type sampler from a depth of $40 \mathrm{~cm}$ from the surface, and they were placed in a size A4 high-density polyethylene bag ${ }^{4}$. In a pretreatment, the sample was dried in a convection oven at $60 \pm 1{ }^{\circ} \mathrm{C}$ for $48-72 \mathrm{~h}$. Once dry, gravel, wood and organic matter were removed from the sample. A 50-g portion of the sample was ground and mixed thoroughly. Major and trace elements were analyzed by X-ray fluorescence spectroscopy (XRF, PANalytical Axios) as follows: $6 \mathrm{~g}$ of the sample were heated at $100{ }^{\circ} \mathrm{C}$ for $24 \mathrm{~h}$ and the sample's moisture was determined. It was then heated at $500{ }^{\circ} \mathrm{C}$ for $30 \mathrm{~min}, 800{ }^{\circ} \mathrm{C}$ for $30 \mathrm{~min}$, and $1000{ }^{\circ} \mathrm{C}$ for $30 \mathrm{~min}$, and the "loss on ignition" was determined. Finally, $1.00 \mathrm{~g}$ of the sample was mixed with lithium borate, melted at 1300 ${ }^{\circ} \mathrm{C}$, and cooled, yielding a crystallized tablet for XRF analysis (duplicate). The samples were analyzed by X-ray diffraction (XRD, Rigaku RINT 2000) using monochromatic $\mathrm{CuK} \alpha$ radiation at $40 \mathrm{kV}$ and $30 \mathrm{~mA}$ in the range of $5^{\circ}$ to $50^{\circ}$ and $10^{\circ}$ to $30^{\circ}$ in $2 \theta$. At the same time, analysis by inductively coupled plasma atomic emission spectroscopy with optical detection (ICP-AES, Seiko SPS7700) was carried out on three sediment samples completely digested in acid medium (with a mixture of $\mathrm{HNO}, \mathrm{HCl}$ and $\mathrm{HF})^{5}$ to determine the trace metals concentration. The detection limits for ICP-AES analysis are (in $\mu \mathrm{g}$
$\left.\mathrm{L}^{-1}\right): 1,1,1.5,20,4,3$ and 1 for $\mathrm{Cr}, \mathrm{Zn}, \mathrm{Cd}, \mathrm{Pb}, \mathrm{Ni}, \mathrm{Co}$ and $\mathrm{Cu}$, respectively. Finally, and as pattern sediment, quality sulfates (SIGMAC) were used for the analysis, without heating. The pure compounds were: $\mathrm{Ca}, \mathrm{Cu}, \mathrm{Fe}, \mathrm{Ni}$ and $\mathrm{Zn}$ in the form of $\mathrm{M}_{\mathrm{x}} \mathrm{SO}_{4} \cdot \alpha \mathrm{H}_{2} \mathrm{O}$.
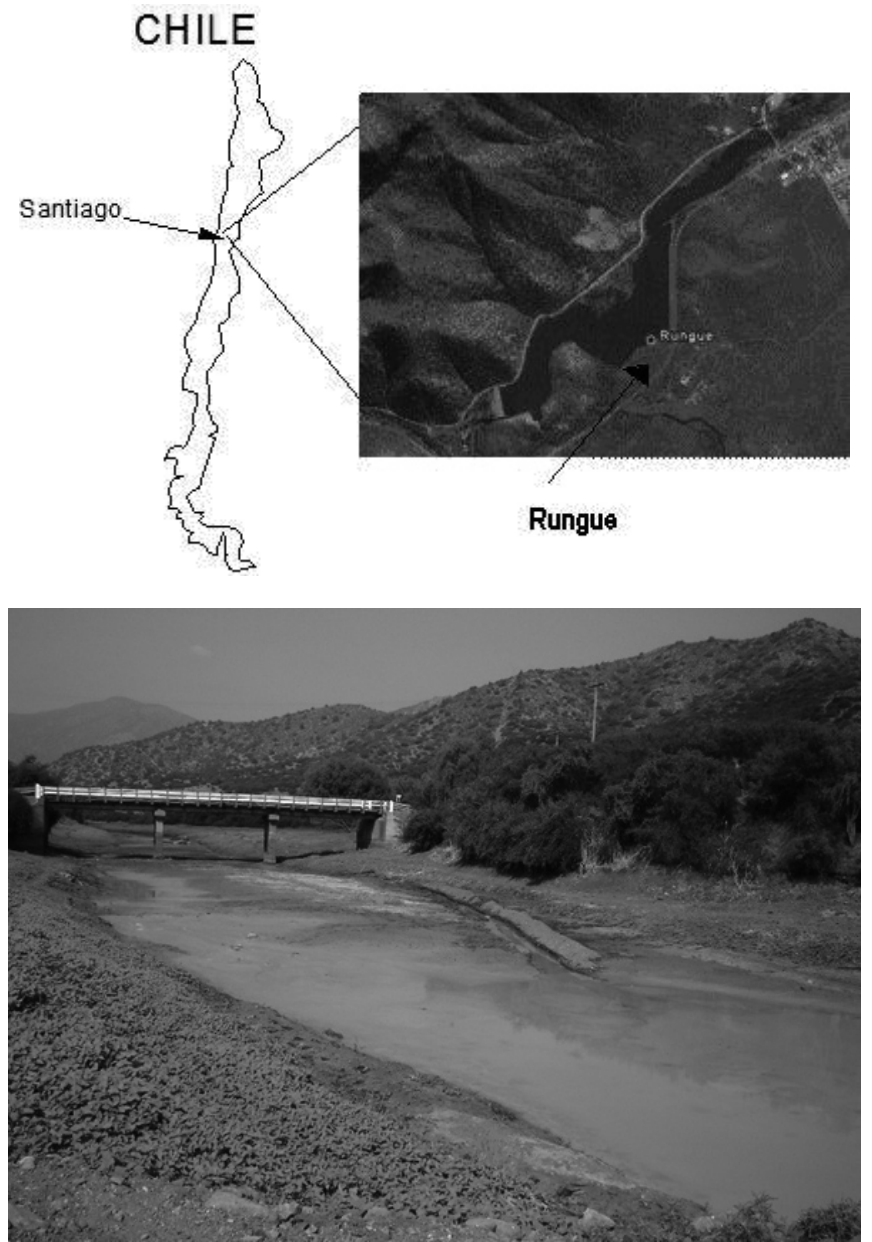

Figure 1. (a) Location of the studied zone and quality of the sediment in the high concentration zone. (b) Characteristics of the water and sediment from the high concentration zone. 
Sequential extraction proposed by the SMT

According to the methodology proposed by the SMT, the four-Step sequential extraction takes place as follows:

\section{Step 1: Extraction with $0.11 \mathrm{~mol} / \mathrm{L}$ acetic acid}

One gram of the sample is treated with a $0.11 \mathrm{~mol} / \mathrm{L}$ acid acetic solution at $\mathrm{pH} \sim 3$. The mixture is stirred continuously at $30 \pm 10 \mathrm{rpm}$ and $22 \pm 5^{\circ} \mathrm{C}$ for $16 \mathrm{~h}$. The extractant is separated from the solid residue by centrifuging at $3000 \mathrm{rpm}$ for $20 \mathrm{~min}$. The supernatant is decanted into polyethylene bottles and stored at $4{ }^{\circ} \mathrm{C}$ for later analysis. The residue is washed by adding $20 \mathrm{~mL}$ of ultrapure water, stirring for $15 \mathrm{~min}$, and centrifuging for $20 \mathrm{~min}$ at $3000 \mathrm{rpm}$. The supernatant is decanted and discarded, taking care not to discard solid particles. In general, trace metals adsorbed on minerals or contained in minerals soluble in weak acid, such as carbonates, can be extracted in this Step.

\section{Step 2: Extraction with $0.5 \mathrm{~mol} / \mathrm{L}$ hydroxylamine hydrochloride}

Forty $\mathrm{mL}$ of $0.5 \mathrm{~mol} / \mathrm{L}$ hydroxylamine hydrochloride solution with the $\mathrm{pH}$ adjusted to 1.5 with $\mathrm{HNO}_{3}$ are added to the residue from Step 1. The mixture is stirred continuously at $30 \pm 10 \mathrm{rpm}$ and $22 \pm 5^{\circ} \mathrm{C}$ for $16 \mathrm{~h}$. The extractant is separated and the residue is treated in the same way as in Step 1. In general, trace metals strongly attached to reducible minerals such as $\mathrm{Fe}$ and Mn hydrooxides can be extracted in this Step.

Step 3: Digestion with $8.8 \mathrm{~mol} / \mathrm{L}$ hydrogen peroxide and extraction with 1 $\mathrm{mol} / \mathrm{L}$ ammonium acetate solution

Ten $\mathrm{mL}$ of $8.8 \mathrm{~mol} / \mathrm{L}$ hydrogen peroxide solution are added carefully to the residue of Step 2. The mixture is digested for $1 \mathrm{~h}$ at $22 \pm 5^{\circ} \mathrm{C}$ and for $1 \mathrm{~h}$ at $85 \pm 2{ }^{\circ} \mathrm{C}$, until the liquid volume has been reduced to less than $3 \mathrm{~mL}$. A second $10-\mathrm{mL}$ aliquot of $8.8 \mathrm{~mol} / \mathrm{L}$ hydrogen peroxide is added to the residue and the mixture is digested again for $1 \mathrm{~h}$ at $85 \pm 2{ }^{\circ} \mathrm{C}$, until the liquid volume is reduced to $1 \mathrm{~mL}$. Finally, $50 \mathrm{~mL}$ of $1 \mathrm{~mol} / \mathrm{L}$ ammonium acetate solution (pH adjusted to $2.0 \pm 0.1$ with $\mathrm{HNO}_{3}$ ) are added to the cold mixture, which is continuously stirred at $30 \pm 10 \mathrm{rpm}$ and $22 \pm 5^{\circ} \mathrm{C}$ for $16 \mathrm{~h}$. The extractant is separated from the solid by centrifugation in the same way as in the previous Steps, collected in polyethylene bottles, and stored at $4{ }^{\circ} \mathrm{C}$ until its later analysis. The residue is washed as in the previous Steps and the supernatant is discarded. In general, trace metals strongly attached to oxidizable minerals such as sulfides and phosphates, ${ }^{6,7}$ and organic matter can be extracted in this Step.

Step 4: Digestion with aqua regia $\left(\mathrm{HNO}_{3}+\mathrm{HCl}\right)$

The residue of Step 3 was digested with aqua regia. Trace metals bonded to silicates and/or oxides ${ }^{8}$ can be extracted in this last Step.

\section{Elemental analysis}

A sample of the Rungue sediment (M1) was analyzed in triplicate by XRF, ICP-AES and XRD. A second sample from the same initial main (M2) was analyzed by XRD in a range of $10^{\circ}$ to $30^{\circ}$. Also, the procedure described above for the first Step of SE was applied in triplicate to one gram of sulfate, as

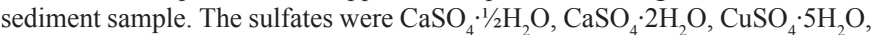
$\mathrm{FeSO}_{4} \cdot 7 \mathrm{H}_{2} \mathrm{O}, \mathrm{NiSO}_{4} \cdot 6 \mathrm{H}_{2} \mathrm{O}$ and $\mathrm{ZnSO}_{4} \cdot 7 \mathrm{H}_{2} \mathrm{O}$ of $90 \%, 95 \%, 99 \%, 99 \%, 99 \%$ and $99 \%$ purity, respectively.

\section{RESULTS AND DISCUSSION}

The results of the XRF and ICP-AES analysis of sample M1 are shown in Tables 1 and 2; values shown correspond to the averages of the triplicate analysis plus its standard deviation, respectively. The result of the analysis of sample M1 by XRD appears in Figure 2. It is seen that sample M1 corresponds to a normal sediment, with high concentrations of silica, aluminum, magnesium, calcium and iron, in agreement with the values for river sediments ${ }^{9}$ However, the values for copper, zinc and nickel in the sediment are much higher than the values measured in the same place (clean zone with $\mathrm{N}=30$; Table 3 ), but also compared to other studies of sediments within Chile ${ }^{10-12}$, which shows a local contamination; and also to other studies of river sediments in the world ${ }^{13}$. The XRD analysis of sample M1 shows the presence of rozenite $\left(\mathrm{FeSO}_{4} \cdot 4 \mathrm{H}_{2} \mathrm{O}\right)$ and gypsum $\left(\mathrm{CaSO}_{4} \cdot 2 \mathrm{H}_{2} \mathrm{O}\right)$. In view of the high concentration of copper, zinc, and nickel in the water (TDS $\sim 1500 \mathrm{mg} / \mathrm{L}$ ) and in the sediment (Table $3)$, and of the high concentration of $\mathrm{SO}_{4}{ }^{2-}$ in the water $(\sim 3800 \mathrm{mg} / \mathrm{L})$, it was assumed that the presence of these sulfates is possible even when they are not detected in the analysis. For the purpose of interpretation, it is assumed that it is possible for these sulfates to exist unconsolidated (not in crystal phase, or amorphous) and that they are present in the analysis at the interference level. Because of the detection of rozenite and gypsum, the first step of the SE was carried out in triplicate by using each time $1 \mathrm{~g}$ of calcium, copper, iron, nickel and zinc sulfate, simulating the sediment. The results of this extraction are shown in Table 4. It is seen that the results of Step 1 of the SE indicate constant extraction greater than $99 \%$ for $\mathrm{Cu}, \mathrm{Fe}, \mathrm{Ni}$ and $\mathrm{Zn}$ sulfates. The variable results for the hydrated $\mathrm{Ca}$ sulfates can be accounted for either by the low presence of water in the compound or by a $\mathrm{pH}$ value above that required for complete dissolving at $\mathrm{pH}<2.5 .^{14}$

Table 1. Results of the XRF analysis of M1 (wt \%).

\begin{tabular}{|c|c|c|c|}
\hline \multicolumn{4}{|c|}{ Sample M1 (Wt\%) } \\
\hline & $\bar{x}$ & & S.D. \\
\hline $\mathrm{SiO}_{2}$ & 41.79 & \pm & 0.437 \\
\hline $\mathrm{FeO}$ & 8.773 & \pm & 0.135 \\
\hline $\mathrm{MgO}$ & 11.01 & \pm & 0.130 \\
\hline L.O.I.* & 6.017 & \pm & 0.177 \\
\hline $\mathrm{CaO}$ & 8.405 & \pm & 0.116 \\
\hline $\mathrm{Al}_{2} \mathrm{O}_{3}$ & 12.42 & \pm & 0.094 \\
\hline $\mathrm{MnO}$ & 1.602 & \pm & 0.022 \\
\hline $\mathrm{K}_{2} \mathrm{O}$ & 2.435 & \pm & 0.034 \\
\hline $\mathrm{Na}_{2} \mathrm{O}$ & 2.481 & \pm & 0.003 \\
\hline $\mathrm{TiO}_{2}$ & 1.271 & \pm & 0.019 \\
\hline $\mathbf{P}_{2} \mathrm{O}_{5}$ & 0.300 & \pm & 0.003 \\
\hline Total & \multicolumn{3}{|c|}{$96.51 \%$} \\
\hline
\end{tabular}

S.D. $=$ Standard deviation

*L.O.I = Loss on ignition. S (carbonates, sulfates, nitrates, etc.)

Table 2. Results of the ICP-AES analysis of M1 (mg L-1) with its concentration and standard deviation.

\begin{tabular}{|c|c|c|c|}
\hline \multirow[b]{2}{*}{ Element } & \multirow[b]{2}{*}{$\begin{array}{c}\text { D.L. } \\
\left(\mu g L^{-1}\right)\end{array}$} & \multicolumn{2}{|c|}{ Sample M1 } \\
\hline & & $\bar{x}$ & S.D. \\
\hline $\mathrm{Cr}$ & 1 & 36.15 & \pm 0.72 \\
\hline Zn & 1 & 901.7 & $\pm \quad 18$ \\
\hline Cd & 1.5 & 17.08 & \pm 0.34 \\
\hline $\mathbf{P b}$ & 20 & 2088 & \pm 41.7 \\
\hline $\mathrm{Ni}$ & 4 & 249.4 & \pm 4.99 \\
\hline Co & 3 & 189.3 & \pm 3.79 \\
\hline $\mathrm{Cu}$ & 1 & 2968 & $\pm \quad 59.4$ \\
\hline
\end{tabular}

D.L. $=$ Detection Limits 
Table 3. Comparison of the ICP-AES analysis of M1 with the average concentration (mg L-1) and its standard deviation of trace metals along the whole river $(\mathrm{N}=30)$

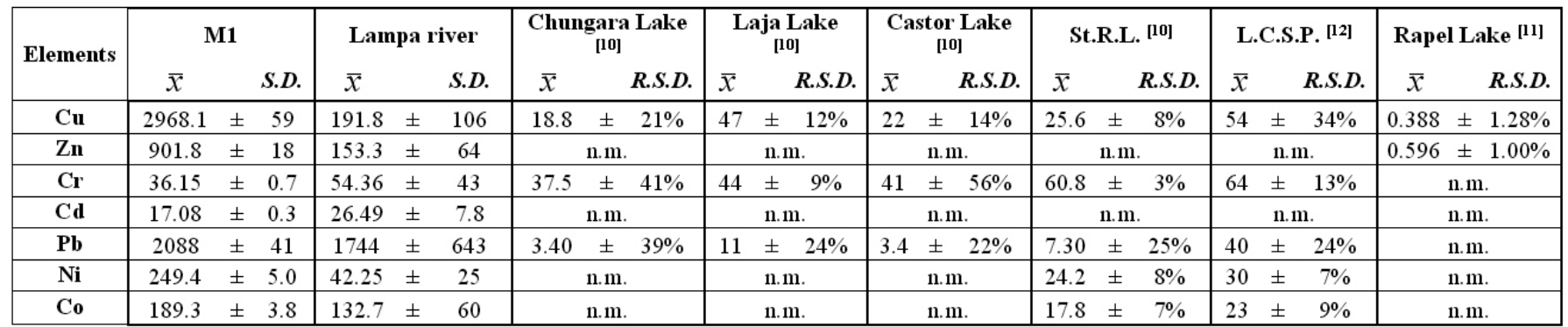

St.R.L. = Saint Rafael Lake; L.C.S.P. $=$ Laguna Chica San Pedro; $\boldsymbol{n} . \boldsymbol{m} .=$ not measured (by the authors)

\section{D1. Use of a $0.11 \mathrm{~mol} / \mathrm{L}$ acetic acid solution in the first step of the} sequential extraction.

According to the extraction method proposed by the SMT, the reason for the use of acetic acid (HOac) in the first Step of the SE has to do with the extraction of metals linked to carbonates ${ }^{15}$. For that purpose HOac is used to extract trace metals either specifically adsorbed or bonded to the outer layer in a range of $5 \%$ of carbonate.

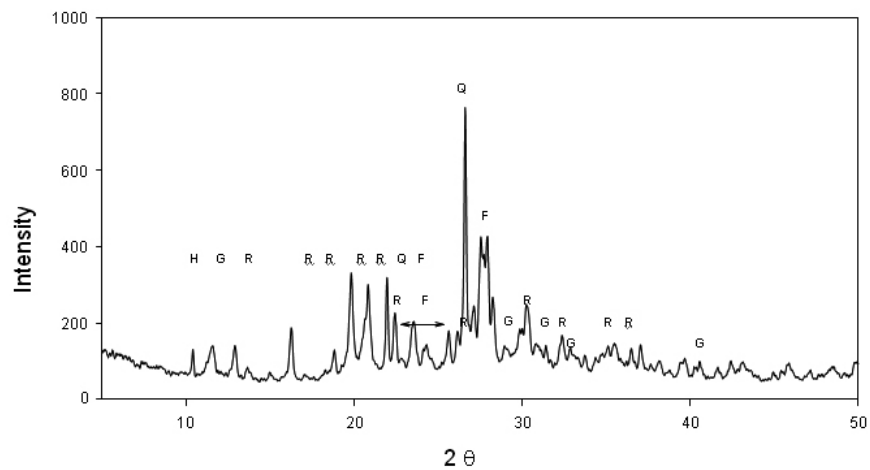

Figure 2. XRD analysis of sample M1.

Q: quartz, H: hornblende, F: feldspar, G: gypsum, R: rozenite HOac

D2. Differences between the $\mathrm{pH}$ values during the use of $0.11 \mathrm{~mol} / \mathrm{L}$

Although the use of HOac in the sequential extraction is quite common, ${ }^{2}$, 3,16 the $\mathrm{pH}$ values associated with this Step $(\mathrm{pH} \sim 4.5)^{3,15,17-20}$ do not agree with the values measured in the laboratory during the preparation of the samples $(\mathrm{pH} 2.80)$. Acetic acid is a weak acid with a dissociation constant $\left(\mathrm{K}_{\mathrm{a}}\right) 1.75 \times 10^{-5}$ at $20^{\circ} \mathrm{C}$. Therefore, a $0.11 \mathrm{~mol} / \mathrm{L}$ solution of HOac will have a $p H=-\log \left(\sqrt{\left(1.75 \times 10^{-5}\right) \times 0.11}=2.85\right.$, a value very close to that found during the preparation of the solution in Step 1 of the SE. This means that the HOac solution proposed by a number of authors must use a buffer like acetate, for example, to keep the $\mathrm{pH} \sim 5$ as proposed originally by Tessier, ${ }^{1}$ something that is not brought up in the papers on SE.

\section{D3. Extraction of sulfates in the first Step of the SE.}

With the purpose of determining experimentally if sulfates are extracted in Step 1 of the SE, a second sample (M2) from the same initial main (M1) was analyzed by XRD to determine the constituent minerals before and after the Step 1 extraction. The results of the analysis (Fig. 3) show clearly that the presence of both gypsum and rozenite before (Fig. 3A) and after (Fig. 3B) Step 1 are in full agreement, showing no sulfates after the SE. It is therefore inferred that the sulfates of trace and/or toxic metals are extracted almost completely (see Table 4) in Step 1 of the SE, suggesting that trace metals that are interchangeable, adsorbed on carbonates, and present as sulfates are extracted in this first step of the SE.

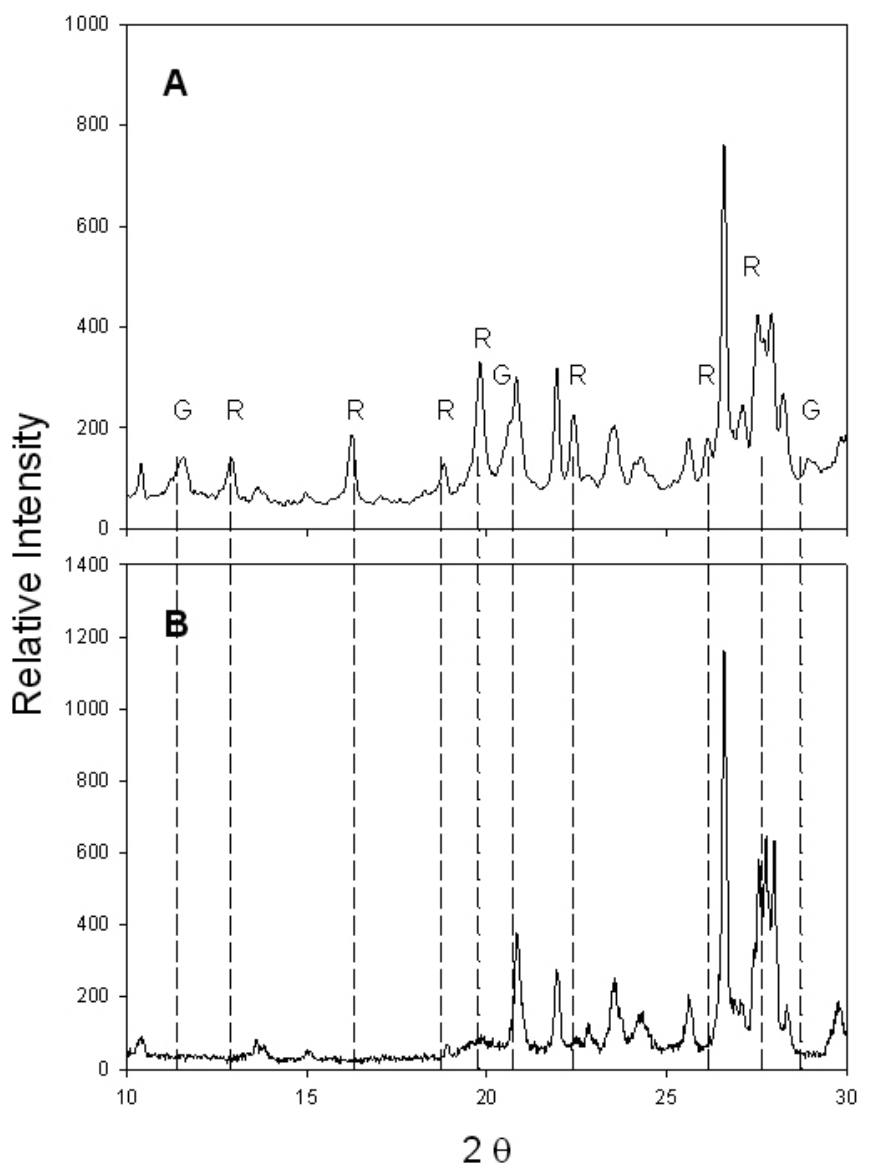

Figure 3. XRD analysis of sample M2 before and after the first stage of SE.

G: gypsum, R: rozenite. 
Table 4. Results of the extraction with $0.11 \mathrm{~mol} / \mathrm{L}$ acetic acid solution for different sulfates.

\begin{tabular}{|c|c|c|c|c|c|c|c|}
\hline & $\begin{array}{c}\text { Molar } \\
\text { mass } \\
(\mathrm{g} / \mathrm{mol})\end{array}$ & $\begin{array}{l}\text { Cation } \\
\text { mass }\end{array}$ & Purity (\%) & $\begin{array}{c}\text { Expected } \\
\text { value } \\
(\mathrm{mg} / \mathrm{l})\end{array}$ & Sample & $\begin{array}{c}\text { Analyzed } \\
\text { value } \\
\left(\mathbf{m g ~ L} \mathrm{L}^{-1}\right)\end{array}$ & $\begin{array}{l}\text { Extraction } \\
\text { yield }\end{array}$ \\
\hline \multirow{3}{*}{ 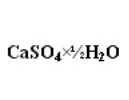 } & \multirow{3}{*}{145.15} & \multirow{3}{*}{40.08} & \multirow{3}{*}{$90 \%$} & \multirow{3}{*}{4970} & A & 800 & $16 \%$ \\
\hline & & & & & B & 801 & $16 \%$ \\
\hline & & & & & $\mathrm{C}$ & 800 & $16 \%$ \\
\hline \multirow{3}{*}{$\mathrm{CaSO}_{4} \times 2 \mathrm{H}_{2} \mathrm{O}$} & \multirow{3}{*}{172.17} & \multirow{3}{*}{40.08} & \multirow{3}{*}{$95 \%$} & \multirow{3}{*}{4423} & A & 2656 & $60 \%$ \\
\hline & & & & & B & 2660 & $60 \%$ \\
\hline & & & & & $\mathrm{C}$ & 2662 & $60 \%$ \\
\hline \multirow{3}{*}{$\mathrm{CuSO}_{4} \times 5 \mathrm{H}_{2} \mathrm{O}$} & \multirow{3}{*}{249.69} & \multirow{3}{*}{63.55} & \multirow{3}{*}{$99 \%$} & \multirow{3}{*}{5039} & $\mathrm{~A}$ & 5003 & $99 \%$ \\
\hline & & & & & B & 4998 & $99 \%$ \\
\hline & & & & & $\mathrm{C}$ & 5000 & $99 \%$ \\
\hline \multirow{3}{*}{$\mathrm{FeSO}_{4} \times 7 \mathrm{H}_{2} \mathrm{O}$} & \multirow{3}{*}{278.02} & \multirow{3}{*}{55.85} & \multirow{3}{*}{$99 \%$} & \multirow{3}{*}{3977} & A & 3959 & $100 \%$ \\
\hline & & & & & B & 3960 & $100 \%$ \\
\hline & & & & & $\mathrm{C}$ & 3961 & $100 \%$ \\
\hline \multirow{3}{*}{$\mathrm{NiSO}_{4} \times 6 \mathrm{H}_{2} \mathrm{O}$} & \multirow{3}{*}{262.85} & \multirow{3}{*}{58.69} & \multirow{3}{*}{$99 \%$} & \multirow{3}{*}{4421} & A & 4390 & $99 \%$ \\
\hline & & & & & B & 4395 & $99 \%$ \\
\hline & & & & & $\mathrm{C}$ & 4395 & $99 \%$ \\
\hline \multirow{3}{*}{$\mathrm{ZnSO}_{4} \times 7 \mathrm{H}_{2} \mathrm{O}$} & \multirow{3}{*}{287.56} & \multirow{3}{*}{65.39} & \multirow{3}{*}{$99 \%$} & \multirow{3}{*}{4502} & A & 4491 & $100 \%$ \\
\hline & & & & & B & 4489 & $100 \%$ \\
\hline & & & & & C & 4491 & $100 \%$ \\
\hline
\end{tabular}

\section{CONCLUSION}

Considering the results obtained from the XRD analysis for sample M2 before and after Step 1 of the sequential extraction, as well as the experiments carried out with $\mathrm{Ca}, \mathrm{Cu}, \mathrm{Fe}, \mathrm{Ni}$ and $\mathrm{Zn}$ sulfates, it is possible to suggest that most of the sulfates of trace or toxic metals can be extracted in the first Step of the SE because of the low $\mathrm{pH}$ value of the HOac solution. However, this new approximation does not alter what was proposed originally by Tessier or later by other authors, but rather extends the interpretation of the first step of the sequential extraction in the study of sediments that can contain sulfates in their natural states or of basins affected by acid contamination of natural or mining origin.

\section{ACKNOWLEDGEMENTS}

The authors wish to thank the government of Japan due its scholarship program Monbukagakusho. Also, the Laboratory of Geochemistry from the University of Tokyo and it's responsible professor, Dr. Takashi Murakami, for his support in the analysis of the samples. Finally, the authors express their tremendous gratitude to E.A., E.L, J.E.F, C.P and S.A. for their kind support in the preparation of this paper.

\section{REFERENCES}

1. A. Tessier, P. G. C. Campbell, and M. Bisson, Anal. Chem., 51, 844 (1979).

2. C. Gleyzes, S. Tellier, and M. Astruc, Trac-Trend. Anal. Chem., 21, 451 (2002).

3. J. Hlavay, T. Prohaska, M. Weisz, W. W. Wenzel, and G. J. Stingeder, Pure.Appl. Chem., 76, 415 (2004).

4. W. D. Weight and J. L. Sonderegger, Manual of Applied Field Hydrogeology 1st ed, 607 pp, McGraw-Hill Professional (2001).

5. E. Standard, E. Standard, Ed. (2003).

6. A. D. Karathanasis, Soil.Sci.Soc.Am.J., 55, 1774 (1991).

7. C. S. Zhang and L. J. Wang, Appl.Geochem., 16, 1251 (2001).

8. A. Mocko and W. Waclawek, Anal.Bioanal.Chem., 380, 813 (2004).

9. L. González, M. Mardones, A. Silva, and E. Campos, Rev.Geol.Chile, (1999).

10. R. Urrutia, M. Yevenes, and R. Barra, J. Chil. Chem. Soc., 47, 457 (2002).

11. J. Pizarro, M. A. Rubio, and X. Castillo, J. Chil. Chem. Soc., 48, 45 (2003).

12. L. Chirinos, R. Urrutia, N. Fagel, S. Bertrand, N. Gamboa, A. Araneda, and C. Zaror, J. Chil. Chem. Soc., 50, 697 (2005).

13. J. I. Drever, Surface and Ground Water, Weathering, and Soils, 1st ed, 400 pp, Elsevier Science (2005).

14. P. M. Kopittke, N. W. Menzies, and I. M. Fulton, Aust.J. Soil. Res., 42, 953 (2004).

15. H. Zeien and G. W. Brümmer, Mittlg. Dtsch. Bodenkdl. Ges., 505 (1989).

16. B. L. Larner, A. J. Seen, and A. T. Townsend, Anal.Chim.Acta, 556, 444 (2006).

17. S. Tokalioglu, S. Kartal, and G. Birol, Turk. J. Chem., 27, 333 (2003).

18. G. Rauret, J. F. Lopez-Sanchez, A. Sahuquillo, E. Barahona, M. Lachica, A. M. Ure, C. M. Davidson, A. Gomez, D. Luck, J. Bacon, M. Yli-Halla, H. Muntau, and P. Quevauviller, J. Environ. Monitor., 2, 228 (2000).

19. G. Sposito, L. J. Lund, and A. C. Chang, p. 260, Soil Sci Soc America (1982).

20. W. P. Miller, D. C. Martens, and L. W. Zelazny, p. 598, Soil Sci Soc America (1986) 